\title{
MONOTONICITY RESULTS AND INEQUALITIES FOR THE GAMMA AND INCOMPLETE GAMMA FUNCTIONS
}

\author{
FENG QI
}

Abstract. In the article, using the monotonicity and inequalities of the generalized weighted mean values with two parameters, we prove that the functions $\left[\frac{\Gamma(s)}{\Gamma(r)}\right]^{1 /(s-r)},\left[\frac{\Gamma(s, x)}{\Gamma(r, x)}\right]^{1 /(s-r)}$ and $\left[\frac{\gamma(s, x)}{\gamma(r, x)}\right]^{1 /(s-r)}$ are increasing in $r>0, s>0$ and $x>0$, where $\Gamma(s), \Gamma(s, x)$ and $\gamma(s, x)$ denote the gamma and incomplete gamma functions with usual notation. From this, some monotonicity results and inequalities for the gamma or incomplete gamma functions are deduced or extended, a unified proof of some known results for the gamma function is given.

Mathematics subject classification (2000): Primary 33B15, 33B20; Secondary 26D07, 26D15, 26A48.

Key words and phrases: Incomplete gamma function, exponential integral, ratio, monotonicity, inequality, generalized weighted mean values with two parameters.

\section{REFERENCES}

[1] H. AlzER, On some inequalities for the gamma and psi functions, Math. Comp. 66 (1997), 373-389.

[2] H. AlzER, On some inequalities for the incomplete gamma function, Math. Comp. 66 (1997), 771-778.

[3] H. AlzER, On some inequalities involving $(n !)^{1 / n}$, Rocky Mountain J. Math. 24 (1994), no. 3, 867-873.

[4] Á. ElBERT AND A. LAFORGIA, An inequality for the product of two integrals relating to the incomplete Gamma function, J. Inequal. Appl. 5 (2000), 39-51

[5] N. Elezović, C. GIORDANO AND J. PeČARIĆ, The best bounds in Gautschi's inequality, Math. Inequal. Appl. 3 (2000), 239-252.

[6] T. ERBER, The gamma function inequalities of Gurland and Gautschi, Scand. Actuar. J. 1960 (1961), $27-28$.

[7] W. GAUTSCHI, Some elementary inequalities relating to the gamma and incomplete gamma function, J. Math. Phys. 38 (1959), 77-81.

[8] B.-N. GuO AND F. QI, Inequalities for generalized weighted mean values of convex function, Math. Inequal. Appl. 4 (2001), no.2, 195-202. RGMIA Res. Rep. Coll. 2 (1999), no.7, Article 11, 1059-1065. Available online at http://rgmia.vu.edu.au/v2n7.html.

[9] J. D. KeČLIĆ AND P. M. VASIĆ, Some inequalities for the gamma function, Publ. Inst. Math. Beograd N. S. 11 (1971), 107-114.

[10] D. KeRSHAW, Some extensions of W. Gautschi's inequalities for the gamma function, Math. Comp. 41 (1983), 607-611.

[11] D. Kershaw And A. LAFORgia, Monotonicity results for the gamma function, Atti Accad. Sci. Torino Cl. Sci. Fis. Mat. Natur. 119 (1985), 127-133.

[12] J.-CH. KuANG, Changyong Budengshi (Applied Inequalities), 2nd edition, Hunan Education Press, Changsha, China, 1993. (Chinese)

[13] A. LAFORGIA, Further inequalities for the gamma function, Math. Comp. 42 (1984), 597-600.

[14] A. LAFORGIA AND S. SISMONDI, Monotonicity results and inequalities for the gamma and error functions, J. Comp. Appl. Math. 23 (1988), 25-33.

[15] E. LeaCh AND M. SHOlANDER, Extended mean values, Amer. Math. Monthly 85 (1978), 84-90. 
[16] M. MERKLE, Some inequalities for the chi squre distribution function, Univ. Beograd. Publ. Elektrotehn. Fak. Ser. Mat. 2 (1991), 89-94.

[17] H. MinC AND L. SATHRE, Some inequalities involving $(r !)^{1 / r}$, Proc. Edinburgh Math. Soc. $14(1965 / 66)$, 41-46.

[18] D. S. Mitrinović, Analytic Inequalities, Springer-Verlag, New York, Heidelberg, Berlin, 1970.

[19] D. S. Mitrinović, J. E. PeČArIĆ AND A. M. FinK, Classical and New Inequalities in Analysis, Kluwer Academic Publishers, Dordrecht, Boston, London, 1993.

[20] B. Palumbo, A generalization of some inequalities for the gamma function, J. Comp. Appl. Math. 88 (1997), 255-268.

[21] F. QI, Generalized abstracted mean values, J. Inequal. Pure and Appl. Math. 1 (2000), no. 1, Article 4. Available online at http://jipam.vu.edu. au/v1n1/013_99.html. RGMIA Res. Rep. Coll. 2 (1999), no. 5, Article 4, 633-642. Available online at http://rgmia.vu.edu .au/v2n5.html.

[22] F. QI, Generalized weighted mean values with two parameters, R. Soc. Lond. Proc. Ser. A Math. Phys. Eng. Sci. 454 (1998), no. 1978, 2723-2732.

[23] F. QI, Logarithmic convexity of extended mean values, Proc. Amer. Math. Soc. 129 (2001), no. 12, in the press. RGMIA Res. Rep. Coll. 2 (1999), no. 5, Article 5, 643-652. Available online at http://rgmia.vu.edu.au/v2n5.html.

[24] F. QI, L.-H. CUI, AND S.-L. XU, Some inequalities constructed by Tchebysheff's integral inequality, Math. Inequal. Appl. 2 (1999), no. 4, 517-528.

[25] F. QI AND S.-L. GUO, Inequalities for the incomplete gamma and related functions, Math. Inequal. Appl. 2 (1999), no. 1, 47-53.

[26] F. QI AND Q.-M. LUO, A simple proof of monotonicity for extended mean values, J. Math. Anal. Appl. 224 (1998), 356-359.

[27] F. QI AND J.-Q. MEI, Some inequalities for the incomplete gamma and related functions, Z. Anal. Anwendungen 18 (1999), no. 3, 793-799.

[28] F. QI, J.-Q. MEI, D.-F. XIA, AND S.-L. XU, New proofs of weighted power mean inequalities and monotonicity for generalized weighted mean values, Math. Inequal. Appl. 3 (2000), no. 3, 377-383.

[29] F. QI, J.-Q. MEI, AND S.-L. XU, Other proofs of monotonicity for generalized weighted mean values, RGMIA Res. Rep. Coll. 2 (1999), no. 4, Article 6, 469-472. Available online at http://rgmia.vu.edu.au/v2n4.html.

[30] F. QI, S.-L. XU, AND L. DEBNATH, A new proof of monotonicity for extended mean values, Internat. J. Math. Math. Sci. 22 (1999), no. 2, 415-420.

[31] F. QI AND SH.-Q. ZHANG, Note on monotonicity of generalized weighted mean values, R. Soc. Lond. Proc. Ser. A Math. Phys. Eng. Sci. 455 (1999), no. 1989, 3259-3260.

[32] H. R. VAN DER VAART, Some extensions of the idea of Bias, Ann. Math. Statist. 32 (1961), 436-447. 